and $77 \%$ in $\mathrm{N}$ and $\mathrm{E}$ groups, respectively) and of IV cyclophosphamide (81 and $77 \%$, respectively).

During the first year, mean (SD) UP/C decreased statistically more in group $\mathrm{E}$ compared to group $\mathrm{N}$ ( $p=0.028$ by ANOVA), with striking differences at month 3 (N: $1.73 \pm 1.87 ; \mathrm{E}: 0.96 \pm 1.34 ; p=0.038$ by unpaired $\mathrm{t}$-test). This difference at month 3 was also noticed for group $P$ patients $(0.85 \pm 0.76 ; p=0.02$ by unpaired t-test). Interestingly, the mean MP dose at month 3 was statistically higher in group E $(19 \pm 8)$ and $P(20 \pm 9)$ compared to group $N(15 \pm 6)$ ( $p=0.005$ by unpaired t-test). At last follow-up, serum creatinine was statistically lower in $\mathrm{E}$ and $\mathrm{P}$ patients compared to $\mathrm{N}$ patients. Eight of the 11 patients from the $\mathrm{T}$ group suffered form a renal relapse, justifying restart of GC, after a median time of 30 months. Importantly, SLICC/ACR-DI was significantly lower in E and $\mathrm{P}$ patients, compared to $\mathrm{N}$ patients ( $p=0.0068$ and 0.0027 , respectively)

Conclusions: In half of LN patients, complete GC withdrawal is achievable and in one third it can be maintained long term. As expected, patients able to stop GC display less damage at last followup. Patients who were able to stop GC decreased their proteinuria much more promptly during the first year of treatment. Interestingly, they received more GC within the first 3 months of therapy, thereby suggesting that a higher dose of GC during the first 3 months of treatment might be associated with a higher probability of later GC withdrawal.

Disclosure of Interest: None declared

DOI: 10.1136/annrheumdis-2017-eular.3132

\section{SAT0239 LATE-ONSET NEUTROPENIA FOLLOWING RITUXIMAB TREATMENT IN SYSTEMIC LUPUS ERYTHEMATOSUS - A ROLE OF THE BAFF/APRIL PATHWAY}

I. Parodis, F. Söder, F. Faustini, F. Wermeling, R.F. van Vollenhoven, E. Svenungsson, I. Gunnarsson. Department of Medicine, Rheumatology Unit, Karolinska Institutet, Stockholm, Sweden

Background: Rituximab-mediated late-onset neutropenia ( $L O N)$ has been studied in various diseases, but data from systemic lupus erythematosus (SLE) are limited. Objectives: To study the prevalence and contributing factors for LON following treatment with rituximab in patients with SLE, including B cell related cytokines and growth factors of the myeloid lineage.

Methods: Patients from the Karolinska SLE cohort treated with rituximab ( $n=107)$ were enrolled in this observational study. Rituximab was given according to the lymphoma course (weekly for four weeks), the arthritis course (at week 0 and 2), or as a single infusion, with or without concomitant pulses of cyclophosphamide. LON was defined as an absolute neutrophil count $<1,500$ cells $/ \mu \mathrm{L}$, occurring four weeks to two years after initiation of rituximab treatment, provided that other apparent causes were excluded. Neutropenia occurring later than two years after treatment initiation but during sustained $B$ cell depletion were also considered LON. B lymphocyte stimulator (BLyS/BAFF), a proliferation-inducing ligand (APRIL), interleukin 6 (IL-6), granulocyte colony stimulating factor (G-CSF) and granulocyte-macrophage colony stimulating factor (GM-CSF) were measured by ELISA prior to treatment $(n=70)$ and either at the incidence of LON in patients who developed LON or after approximately the same median time following rituximab treatment in patients who did not develop LON $(n=52)$.

Results: Thirty-four of 107 patients developed LON after a median time of 222 days (IQR: 105-355 days). BLyS levels increased from baseline (median: $0.62 \mathrm{ng} / \mathrm{mL}$; IQR: $0.42-1.07 \mathrm{ng} / \mathrm{mL}$ ) through the post-treatment measurement, both in patients who developed LON (median: $1.73 \mathrm{ng} / \mathrm{mL}$; IQR: 1.03-2.13 $\mathrm{ng} / \mathrm{mL} ; \mathrm{P}=0.005$ ) and patients who did not (median: 1.03 ; IQR: $0.67-1.56 \mathrm{ng} / \mathrm{mL}$; $\mathrm{P}<0.001$ ), but the increase was greater in patients who developed LON, resulting in significantly higher post-treatment BLyS levels $(P=0.029)$. BLyS levels did not differ between the two groups at baseline $(P=0.745)$. We observed a numerical increase in APRIL levels from baseline (median: $1.29 \mathrm{ng} / \mathrm{mL}$; IQR: 0.85-2.3 $\mathrm{ng} / \mathrm{mL}$ ) through the post-treatment measurement in patients who developed LON (median: 2.39; IQR: $1.08-5.16 \mathrm{ng} / \mathrm{mL} ; \mathrm{P}=0.074$ ) and a numerical decrease in patients who did not (median: $1.11 \mathrm{ng} / \mathrm{mL}$; IQR: $0.77-1.64 \mathrm{ng} / \mathrm{mL} ; \mathrm{P}=0.064$ ), resulting in significantly higher post-treatment APRIL levels in the LON group $(P=0.032)$, from being similar at baseline $(P=0.125)$. We found no difference in levels of G-CSF, GM-CSF or IL- 6 between patients who developed LON and patients who did not, either at baseline or at the post-treatment measurement. Higher prednisone dose administered concomitantly to rituximab $(P=0.003)$ and younger age $(P=0.001)$ were found to be associated with the development of LON, whereas neither the use nor the doses of cyclophosphamide were found to have any impact.

Conclusions: The prevalence of rituximab-mediated LON within the SLE patients of the current study $(31.8 \%)$ was higher compared to previous reports on patients with lymphoma (3-27\%), ANCA-associated vasculitis $(11.9 \%)$ and rheumatoid arthritis $(3 \%)$. Our results imply a role of the BAFF/APRIL pathway in the immunologic mechanisms underlying this phenomenon and demonstrate that LON following rituximab treatment is a common complication in SLE patients. Disclosure of Interest: None declared

DOI: 10.1136/annrheumdis-2017-eular.6160

\section{SAT0240 PHASE 3 TRIAL RESULTS WITH BLISIBIMOD, A SELECTIVE INHIBITOR OF B-CELL ACTIVATING FACTOR, IN SUBJECTS WITH SYSTEMIC LUPUS ERYTHEMATOSUS (SLE)}

J. Merrill $^{1}$, R.S. Martin ${ }^{2}$, W.R. Shanahan ${ }^{2}$, M. Scheinberg ${ }^{3}$, K. Kalunian ${ }^{4}$, D. Wofsy ${ }^{5} .{ }^{1}$ OMRF, Oklahoma; ${ }^{2}$ ANTHERA, Hayward, United States; ${ }^{3}$ Hospital Abreu Sodré, Sao Paolo, Brazil; ${ }^{4}$ UCSD, San Diego; ${ }^{5}$ UCSF, San Francisco, United States

Background: Targeted, biologic inhibitors of B-cell Activating Factor (BAFF) have been evaluated in Phase 3 trials in over 5000 patients with SLE. Post hoc analyses of these studies identify lower placebo response and greater treatment effect using more stringent endpoints in patients entering with higher disease activity, greater corticosteroid doses, and/or anti-double-stranded DNA (dsDNA) and low complement $\mathrm{C} 3$ or $\mathrm{C}^{1,2}$.

Objectives: The Phase 3 CHABLIS-SC1 trial evaluated blisibimod, an inhibitor of B-cell activating factor (BAFF), in a "responder population" identified from prior studies with this drug class.

Methods: 442 SLE patients with anti-nuclear antibodies or anti-dsDNA, SELENASLEDAI score $\geq 10$ on standard of care medications were randomized to receive weekly subcutaneous blisibimod $(200 \mathrm{mg})$ or placebo. Corticosteroid taper was encouraged from Week 8 with the goal to reach $\leq 7.5 \mathrm{mg}$ prednisone/day. The primary endpoint at Week 52 was the SLE Responder Index-6 (SRI-6): $\geq 6$-point improvement in SELENA-SLEDAI, no new BILAG $1 \mathrm{~A}$ or $2 \mathrm{~B}$ domain scores, and $<0.3$-point increase in Physician's Global Assessment.

Results: This study did not meet its primary endpoint at Week 52. Response rates to blisibimod were equivalent to past trials of BAFF inhibitors, but the placebo response was greater. A slightly higher proportion of subjects on blisibimod met the SRI- 6 and SRI- 4 criteria at most timepoints and more blisibimod-treated subjects achieved corticosteroid taper to prednisone $<7.5 \mathrm{mg} /$ day from Week 40 through Week $52(p=0.04$ at Week 44). Reductions in peripheral B cell lineages, anti-dsDNA, anti-phospholipid antibodies, and serum immunoglobulins, and increases in complement C3 and C4 were observed with blisibimod (see Table).

Blisibimod was well-tolerated. The most common adverse events were upper respiratory tract infection $(10.6 \%$ vs $14.3 \%$ on placebo), urinary tract infection $(6.9 \%$ vs $10.7 \%)$, injection site erythema ( $7.8 \%$ vs $2.0 \%)$, injection site reaction ( $7.3 \%$ vs $2.6 \%)$, and diarrhea $(7.3 \%$ vs $2.6 \%)$.

Table of Results Blisibimod ( $\mathrm{N}=245)$ Placebo $(\mathrm{N}=197)$

Disease characteristics at baseline

SELENA-SLEDAI mean score

Low C3/C4 \& anti-dsDNA, \%

Proteinuria $\geq 0.5 \mathrm{~g} / \mathrm{g}, \%$

Mean prednisone dose, $\mathrm{mg}$

Oral immunosuppressant use, $\%$

Antimalarial use, \%

Results at Week $52\left({ }^{*} p<0.05,{ }^{* *} p<0.01\right)$

SRI-6 (primary), \%

SRI-4,\%

Taper to $\leq 7.5 \mathrm{mg}$ prednisone/day, $\%$

Total B cell change from baseline, counts

Anti-dsDNA change from baseline, IU

$\mathrm{C} 3$ and $\mathrm{C} 4$ change from baseline, $\mathrm{mg} / \mathrm{dL}$

Anticardiolipin IgG \% change from baseline

\begin{tabular}{cc}
13.4 & 13.5 \\
62.4 & 61.7 \\
32.7 & 27.9 \\
15.6 & 15.6 \\
42.4 & 41.6 \\
61.2 & 62.2 \\
& \\
46.9 & 42.3 \\
56.7 & 52.0 \\
23.3 & 16.9 \\
$-3.30^{\star \star}$ & -1.58 \\
-134.8 & -75.5 \\
$0.11^{\star \star}, 0.03^{\star \star}$ & $0.03,-0.002$ \\
$-12.7^{\star}$ & 9.3 \\
\hline &
\end{tabular}

Conclusions: With a deliberate focus on a "responder population" for whom lower placebo rates were observed in previous trials, much higher placebo response rates were observed in the CHABLIS-SC1 trial. Modest benefits of blisibimod were observed on serological effects and corticosteroid tapering.

References:

[1] van Vollenhoven RF et al. Ann Rheum Dis. 2012;71:1343.

[2] Merrill JT et al. Ann Rheum Dis. 2016;75(2):332-40.

Disclosure of Interest: J. Merrill Grant/research support from: BMS, GSK, Consultant for: Anthera, GSK, EMD Serono, Lilly, Astra Zeneca, BMS, UCB, Celgene, Biogen, R. Martin Shareholder of: Anthera, Employee of: Anthera, W. Shanahan Shareholder of: Anthera, Employee of: Anthera, M. Scheinberg Consultant for: GSK,Pfizer, Janssen, Genzyme,Anthera, Novartis, Speakers bureau: GSK,Pfizer, Janssen, Genzyme,Anthera, Novartis, K. Kalunian Grant/research support from: GSK, Celgene, UCB, Consultant for: Anthera, Genentech, BMS, Lilly, Biogen, Shire, Exagen, D. Wofsy Consultant for: Anthera, Genentech, Amgen, GSK DOI: 10.1136/annrheumdis-2017-eular.2400

\section{SAT0241 EARLY RESPONSE TO BELIMUMAB IN SLE-RELATED JOINT INVOLVEMENT EVALUATED BY ULTRASONOGRAPHIC ASSESSMENT}

L. Massaro, F. Ceccarelli, F.R. Spinelli, F. Morello, C. Perricone, F. Miranda, S. Truglia, V. Orefice, I.M. Rutigliano, C. Alessandri, G. Valesini, F. Conti. Medicina Interna e Specilità Mediche, Reumatologia, Sapienza Università di Roma, Roma, Italy

Background: Belimumab (BLM), a fully human monoclonal antibody directed against B lymphocyte stimulator (BLyS), is currently the only biological drug 
approved for the treatment of active Systemic Lupus erythematosus (SLE) patients not responding to standard of care. Data from RCTs and observational studies have demonstrated its efficacy, especially in patients with joint involvement. Focusing on this specific manifestation, the response has been also demonstrated by using Disease Activity Score on 28 joints (DAS28) (1). No data are available about the response to BLM in terms of synovitis, assessed by ultrasonography (US).

Objectives: In the present 6-months longitudinal study, we evaluated the response to BLM in SLE patients treated for joint involvement, by using clinimetric indices and US assessment.

Methods: SLE patients starting BLM in the period between August 2013 and December 2016 were prospectively examined. The present analysis was restricted to patients requiring BLM for joint involvement. A complete physical examination and US assessment were performed at baseline (TO) and after 3 (T3) and 6 months (T6). At each time, we assessed the global disease activity by Systemic Lupus Erythematosus Disease Activity Index-2000 (SLEDAI-2K) and the joint involvement activity by DAS28. US evaluation of 12 joints (I-V metacarpophalangeal, I-V proximal interphalangeal, wrist and knee bilateral) was performed to identify inflammatory features (synovial effusion and hypertrophy, power Doppler) according to the OMERACT definitions. These elementary lesions were scored according to a semi-quantitative scale $(0=a b s e n t, 1=$ mild, $2=$ moderate and $3=$ severe) and a total score, corresponding to the patient's inflammatory status $(0-216)$ was obtained by their sum.

Results: Moving from 35 SLE patients starting BLM, 14 (14 female; mean age + SD $48.4 \pm 8.6$ years; mean disease duration $\pm S D$ 255.4 \pm 124.2 months) were treated for prevalent joint involvement. At baseline, the mean DAS28 \pm SD was $4.5 \pm 1.1$, the mean SLEDAI-2K \pm SD was $6.1 \pm 1.5$ and the mean daily prednisone \pm SD was $7.8 \pm 3.5 \mathrm{mg}$. After 3 months of treatment we observed a significant reduction in mean DAS28 ( $3.1 \pm 0.8$ vs $4.5 \pm 1.1, \mathrm{P}=0.007)$ and in mean SLEDAl-2K ( $3.5 \pm 2.1$ vs $6.1 \pm 1.5, P=0.003)$ compared to baseline. The mean daily prednisone significantly decreased at $T 6(4.7 \pm 1.4$ vs $7.8 \pm 3.5 \mathrm{mg}, \mathrm{P}=0.03)$ while the rest of the therapy remained stable for 6 months. Of note, the mean total US score significantly decreased at T3 compared to T0 $(13.7 \pm 24.4$ vs $22.2 \pm 22.6, P=0.001)$. This result was maintained in 12 patients (85.7\%) after 6 months with a statistically significant difference compared to T0 (7.9 \pm 6.6 vs $22.2 \pm 22.6, \mathrm{P}=0.003$ ) (Figure 1).

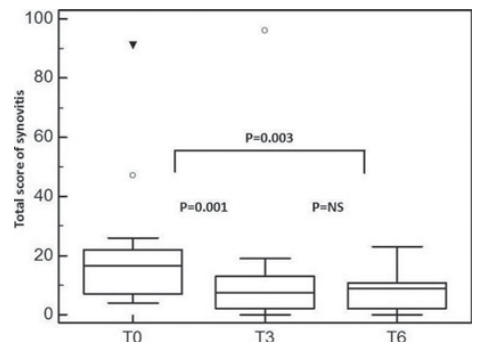

Conclusions: The results of the present study demonstrated the efficacy of BLM in SLE-related joint involvement, evaluated by SLEDAI-2K and DAS28, confirming previous data reported in the scientific literature. For the first time, we demonstrated an early response to BLM as proved by the reduction of the total US synovitis score after 3 months, reflecting the improvement of the joint inflammatory status.

References:

[1] laccarino $L$ et al. Effects of Belimumab on Flare Rate and Expected Damage Progression in Patients With Active Systemic Lupus Erythematosus. Arthritis Care Res. 2017; 69:115-123.

Disclosure of Interest: None declared

DOI: 10.1136/annrheumdis-2017-eular.4238

\section{SAT0242 MEASURES OF PERIPHERAL BLOOD B-CELL DEPLETION PREDICT RENAL RESPONSE IN PATIENTS WITH LUPUS NEPHRITIS TREATED WITH RITUXIMAB}

L.M. Gomez Mendez ${ }^{1}$, M.D. Cascino ${ }^{2}$, J. Garg ${ }^{2}$, P. Brunetta ${ }^{2}$, M. Dall'Era ${ }^{1}$, L. Dragone ${ }^{2} .{ }^{1}$ UCSF; ${ }^{2}$ Genentech, San Francisco, United States

Background: LUNAR, a randomized controlled trial, investigated the addition of rituximab (RTX) to standard of care for the treatment of lupus nephritis (LN). While this study did not meet its primary endpoint, there was an increase in partial renal response associated with RTX. Subsequent observational studies have suggested that there is variability in the degree of peripheral blood B-cell depletion in patients with SLE following treatment with RTX and that greater B-cell depletion may result in increased therapeutic efficacy.

Objectives: To assess the relationship between parameters of B-cell depletion and measures of renal response in patients treated with RTX.

Methods: We analyzed data from the LUNAR trial (registry number NCT00282347) who were treated with RTX and for whom complete CD19 measurements and renal endpoints were available $(n=70)$. We developed several parameters to assess the degree, duration and rate of depletion of CD19 counts from randomization through day 364. Complete renal response (CRR) was defined as urine protein to creatinine ratio (UPCR) $<0.5$, normal serum creatinine or, if normal at baseline, not increased by $\geq 15 \%$, and inactive urinary sediment. Spearman's correlation was used to identify associations between baseline characteristics and measures of B-cell depletion. The association between measures of B-cell depletion and CRR (at weeks 52 and 78) was examined using logistic regression adjusted for baseline UPCR. Separately, analyses were stratified by baseline anti-double stranded DNA antibody titer status (anti-dsDNA).

Results: Baseline UPCR correlated with the degree of B-cell depletion following RTX treatment by several measures (time spent at $C D 19=0$ cells $/ \mathrm{ml}[\mathrm{r}=-0.32]$; CD19 nadir $[r=0.33]$; percent change from baseline to nadir $[r=0.3])$. Measures of B-cell depletion were associated with CRR and percent change in UPCR at week 78 (Table 1). Achievement of a nadir of $\mathrm{CD} 19=0 \mathrm{cells} / \mathrm{ml}$ had an odds ratio (OR) $=5.18(95 \% \mathrm{Cl}: 1.03-26.1)$; patients who spent greater than the median percent of time at $\mathrm{CD} 19=0 \mathrm{cells} / \mathrm{ml}$ had $\mathrm{OR}=3.3(95 \% \mathrm{Cl}: 1.14-9.62)$ for $\mathrm{CRR}$ at week 78. In subgroup analyses, associations between these measures of peripheral blood B-cell depletion and renal response were strongest among patients with high baseline anti-dsDNA titer. No measures of B-cell depletion were associated with CRR at week 52

Table 1. Adjusted multivariate measures of B-cell depletion and their associations with complete renal response and percent change from baseline UPCR.

\begin{tabular}{|c|c|c|c|c|}
\hline & \multicolumn{2}{|c|}{$\begin{array}{l}\text { OR of Complete Renal Response } \\
\qquad(95 \% \mathrm{Cl})\end{array}$} & \multicolumn{2}{|c|}{$\begin{array}{l}\text { Percent change in UPCR } \\
(95 \% \mathrm{Cl})\end{array}$} \\
\hline & Week 52 & Week 78 & Week 52 & Week 78 \\
\hline $\begin{array}{l}\text { CD19 reaches } 0 \text { cells } / \mu l \text { at } \\
\text { any time point }\end{array}$ & $\begin{array}{c}2.12 \\
(0.49,9.07)\end{array}$ & $\begin{array}{c}5.18 \\
(1.03,26.08)\end{array}$ & $\begin{array}{c}-18.9 \% \\
(-42.7,4.88)\end{array}$ & $\begin{array}{c}-31.8 \% \\
(-70.7,7.01)\end{array}$ \\
\hline $\begin{array}{l}\text { Above median percent of } \\
\text { time at } 0 \text { cells/ } \mu \mathrm{l}\end{array}$ & $\begin{array}{c}1.23 \\
(0.41,3.67)\end{array}$ & $\begin{array}{c}3.32 \\
(1.14,9.62)\end{array}$ & $\begin{array}{l}-11.28 \% \\
(-31,8.5)\end{array}$ & $\begin{array}{c}-39.5 \% \\
(-68.2,-10.8)\end{array}$ \\
\hline $\begin{array}{l}\text { Area under the curve for all } \\
B \text { cell measurements in one } \\
\text { year }\end{array}$ & $\begin{array}{c}0.78 \\
(0.38,1.59)\end{array}$ & $\begin{array}{c}1.88 \\
(0.90,3.94)\end{array}$ & $\begin{array}{c}-1.87 \% \\
(-15.4,11.6)\end{array}$ & $\begin{array}{c}1.15 \% \\
(-19.6,22.6)\end{array}$ \\
\hline $\begin{array}{l}\text { For every } 30 \text { of days spent } \\
\text { at } 0 \text { cells } / \mu l\end{array}$ & $\begin{array}{c}1.11 \\
(0.89,1.38)\end{array}$ & $\begin{array}{c}1.16 \\
(0.95,1.4\end{array}$ & $\begin{array}{c}-2.7 \% \\
(-6.9,1.38)\end{array}$ & $\begin{array}{c}-6.18 \% \\
(-12.3,0.06)\end{array}$ \\
\hline Percent of visits at 0 cells $/ \mu l$ & $\begin{array}{c}1.01 \\
(0.98,1.05)\end{array}$ & $\begin{array}{c}1.03 \\
(1.00,1.06)\end{array}$ & $\begin{array}{c}-0.45 \% \\
(-1.06,0.15)\end{array}$ & $\begin{array}{c}-1.05 \% \\
(-1.93,-0.17)\end{array}$ \\
\hline $\begin{array}{l}\text { Every increment of } 30 \text { days } \\
\text { to nadir }\end{array}$ & $\begin{array}{c}(0.98,1.05) \\
1.06 \\
(0.9,1.25)\end{array}$ & $\begin{array}{c}(1.00,1.06) \\
0.92 \\
(0.78,1.08)\end{array}$ & $\begin{array}{c}(-1.06,0.15) \\
-0.72 \% \\
(-3.81,2.34)\end{array}$ & $\begin{array}{c}-1.93,-0.17) \\
1.05 \% \\
(-3.6,5.7)\end{array}$ \\
\hline $\begin{array}{l}\text { Percent change in CD19 } \\
\text { from baseline to nadir }\end{array}$ & $\begin{array}{c}0.74 \\
(0.36,1.53)\end{array}$ & $\begin{array}{c}0.56 \\
(0.25,1.28)\end{array}$ & $\begin{array}{c}0.01 \% \\
(-11.4,11.4)\end{array}$ & $\begin{array}{c}23 \% \\
(-0.84,46.9)\end{array}$ \\
\hline CD19 nadir & $\begin{array}{c}0.00,1.00) \\
0.49 \\
(0.12,1.94)\end{array}$ & $\begin{array}{c}0.25 \\
0.22 \\
(0.04,1.12)\end{array}$ & $\begin{array}{c}19.5 \% \\
(-2.33,41.4)\end{array}$ & $\begin{array}{c}28.4 \% \\
(-7.06,63.8)\end{array}$ \\
\hline
\end{tabular}

$O R$, odds ratio: UPCR, urine protein to creatinine ratio.

Conclusions: Baseline UPCR was inversely correlated with the degree of peripheral B-cell depletion. B-cell depletion measures were associated with increased odds of achieving CRR and decreased UPCR at week 78 and these associations were strongest among patients with high baseline anti-dsDNA titer. These data support the exploration of high-sensitivity B-cell measurements in future studies of B-cell depleting treatments in $L N$ and suggest that longer duration of follow up may better demonstrate efficacy with B-cell depleting agents.

References:

[1] Rovin Arthritis Rheum 2012

[2] Vital Arthritis Rheum 2011.

Disclosure of Interest: L. Gomez Mendez Grant/research support from: Genentech/Roche, M. Cascino Employee of: Genentech/Roche, J. Garg Employee of: Genentech/Roche, P. Brunetta Employee of: Genentech/Roche, M. Dall'Era: None declared, L. Dragone Employee of: Genentech/Roche

DOI: 10.1136/annrheumdis-2017-eular.5412

\section{SAT0243 EXPOSURE-RESPONSE (E-R) ANALYSIS FOR SELECTION OF OPTIMAL DOSAGE REGIMEN OF ANIFROLUMAB IN PATIENTS (PTS) WITH SYSTEMIC LUPUS ERYTHEMATOSUS (SLE)}

L.C. Santiago $^{1}$, B. Wang ${ }^{1}$, P. Brohawn ${ }^{2}$, L. Wang ${ }^{2}$, G. Illei ${ }^{2}$, L. Roskos ${ }^{2}$. ${ }^{1}$ Medlmmune LLC, Mountain View; ${ }^{2}$ Medlmmune LLC, Gaithersburg, United States

Background: Anifrolumab is a fully human $\lg _{1}$ monoclonal antibody directed against subunit 1 of the type I interferon- $\alpha$ receptor (IFNAR1). It is in development for treatment of SLE.

Objectives: To support dosage selection for pivotal anifrolumab studies, using an E-R model.

Methods: In the Phase Ilb MUSE study (NCT01438489), ${ }^{1}$ adult pts with moderate to severe SLE, who had inadequate responses to standard-of-care (SOC) medications, were randomized $1: 1: 1$ to intravenous anifrolumab 300 or $1,000 \mathrm{mg}$ or placebo every 4 weeks (Q4W), in addition to SOC medications, for 48 weeks. Pts were stratified by type I interferon gene signature (IFNGS) test status (high or low) using a validated 4-gene expression assay, oral corticosteroid dosage ( $<10$ or $\geq 10 \mathrm{mg} /$ day of prednisone or equivalent), and SLE disease activity index $-2 \mathrm{~K}$ score $(<10$ or $\geq 10)$ at screening. A mechanistic targetmediated drug disposition model ${ }^{2}$ was used to describe the pharmacokinetics (PK) of anifrolumab. The dichotomous efficacy endpoint, SLE responder index [SRI (4)], was modeled using logistic regression. A dropout hazard function was used to describe voluntary withdrawals during treatment. Clinical simulations were conducted to assess dosing scenarios in virtual SLE pts.

Results: There was no PK difference between type I IFNGS test-high or -low pts (mean [standard deviation] $\mathrm{C}_{\text {trough }}$ (Day 169): 17.0 [11.5] $\mu \mathrm{g} / \mathrm{mL}$ and 23.3 [16.0] $\mu \mathrm{g} / \mathrm{mL}$, respectively). SRI (4) modeling demonstrated no anifrolumab treatment effect in type I IFNGS test-low pts compared with placebo; interpretation of this 